0016-7037(95)00013-5

\title{
A novel triterpenoid carbon skeleton in immature sulphur-rich sediments
}

\author{
Stefan Schouten, JaAp S. Sinninghe Damsté, and Jan W. de Leeuw \\ Division of Marine Biogeochemistry, Netherlands Institute for Sea Research (NIOZ), P.O. Box 59, \\ 1790 AB Den Burg, Texel, The Netherlands
}

(Received August 16, 1994; accepted in revised form December 1, 1994)

\begin{abstract}
A novel $S$ compound, 1,4-bis $\left(2^{\prime}, 5^{\prime}, 5^{\prime}, 8 a^{\prime}\right.$-tetramethylhexahydrothiochroman $)$-butane has been detected in several immature $S$-rich sediments, of which the desulphurized counterpart was unambiguously identified by synthesis of an authentic standard and coinjection experiments. This $\mathrm{C}$ skeleton of the $S$ compound, 1,10-bis $\left(2^{\prime}, 2^{\prime}, 6^{\prime}\right.$-trimethylcyclohexyl $)$-3,8-dimethyldodecane( $\mathrm{I}$ ), has not been reported yet in any sediment or organism. We suggest that it may be biosynthesized through an enzymatic cyclization reaction of squalene (II), which shows similarities with the biosynthesis of $\beta, \beta$-carotene (III) from lycopene (IV).
\end{abstract}

\section{INTRODUCTION}

From the time that gas chromatography coupled with mass spectrometry became a routine analytical technique in the field of organic geochemistry numerous compounds have been identified in sediments and crude oil (e.g., Johns, 1986; Philp, 1985; Peters and Moldowan, 1993; references cited therein ). One of the ultimate aims of biomarker studies is to relate compounds present in the geosphere with those present in the biosphere. Since the structure of many of these compounds can be severely altered due to diagenetic alterations, this task is not always straightforward. Nevertheless, a large suite of compounds has been identified which provide assistance in the reconstruction of the original biota in the depositional environment (e.g., Peters and Moldowan, 1993). Some compounds, like for instance, highly branched isoprenoids, were even detected in crude oils and sediments first (Yon et al., 1982), before they were detected in organisms (Nichols et al., 1988; Volkman et al., 1994).

Organic $S$ compounds in sediments and crude oil constitute a class of compounds which can reveal unique information about their precursor paleobiochemicals. Since these compounds are formed by a reaction of inorganic $S$ species with functionalized lipids (Sinninghe Damsté et al., 1989; De Graaf et al., 1992) these compounds do not only contain information about the $\mathrm{C}$ skeletons of these lipids, but also information on the position and number of functionalities. In this way, a detailed reconstruction of paleobiochemicals is possible. Cyclic triterpenoids, derived from enzymatic cyclization reactions of squalene or its epoxide, are compounds which are often detected in a sulphurized form since they usually contain a number of double bonds suitable for S-incorporation. For example sulphurized hopane, sterane, oleanane, and gammacerane $\mathrm{C}$ skeletons are some of the compounds detected in S-rich sediments (e.g., Schmid, 1986; Sinninghe Damsté et al., 1989; Payzant et al., 1986; Kohnen et al., 1991; Adam et al., 1991). Since a number of these compounds are unique for certain organisms, they are very useful as biomarkers.

Here we report the identification of a novel sulphur compound present in several immature S-rich sediments. Its unprecedented triterpenoid $\mathrm{C}$ skeleton which was unambigu- ously identified, points to the existence of a novel biochemical as yet not discovered in Nature.

\section{EXPERIMENTAL}

\section{Samples}

The Shell Beach sample is from an immature outcrop of the Miocene Monterey Formation (California, USA). The hydrocarbon and organic sulphur compound composition are described by Schouten et al. (1995). The Vena del Gesso sample is from a marl of an evaporitic cycle from the Messinian Vena del Gesso basin in the northern Apemines (Italy). The organic sulphur compounds and other hydrocarbons are described by Kohnen et al. (1992). The JED-sample is from the Cretaceous Jurf ed Darawish oil shale (Jordania). Organic sulphur compounds present in the extract are described by Kohnen et al. (1990).

\section{Extraction and Fractionation}

The sediments were extracted with a dichloromethane/methanol $(7: 1 \mathrm{v} / \mathrm{v})$ mixture. The alkylsulphide fractions were isolated from the extracts by column chromatography and preparative argentation thin layer chromatography as described previously (Kohnen et al., 1992). The alkylsulphide fraction was desulphurized by dissolving it in ca. $4 \mathrm{~mL}$ of cyclohexane and adding ca. $0.5 \mathrm{~g}$ of Raney nickel. The tube was sealed and heated at $200^{\circ} \mathrm{C}$ for $3 \mathrm{~h}$. The suspension was centrifuged and the residue was washed with dichloromethane $(2 \times)$. The combined supernatants were washed with bidistilled water and subsequently dried using $\mathrm{MgSO}_{4}$. The reaction mixture was then hydrogenated by first dissolving it in $99 \%$ acetic acid and adding $\mathrm{PtO}_{2}$. Hydrogen was then bubbled through the solution for $3 \mathrm{~h}$ and the mixture was stirred for an additional $72 \mathrm{~h}$. The acetic acid was removed by washing with bidistilled water and following the workup procedure described above for the Raney nickel desulphurization. The product mixture was analyzed by gas chromatography (GC) and gas chromatography mass spectrometry (GC-MS).

\section{Synthesis of Standard (Fig. 1)}

To a stirred suspension of $20 \mathrm{~mL}$ dry diethylether and $0.3 \mathrm{~g}$ of magnesium curls, $1.8 \mathrm{~mL}(1.1 \mathrm{~g})$ of 1,4-dibromobutane was slowly added under a nitrogen atmosphere. After several minutes of stirring at room temperature, $1.8 \mathrm{~mL}(1.9 \mathrm{~g})$ of $\beta$-ionone was slowly added. The solution was then refluxed for $3 \mathrm{~h}$. The reaction mixture was extracted with diethylether. Subsequently, an aliquot of the reaction products was dehydrated by dissolving it in $85 \% \mathrm{H}_{3} \mathrm{PO}_{4}$ and stirring at room temperature for $1 \mathrm{~h}$. The products were extracted with diethylether. Finally, an aliquot of the dehydrated reaction products was hydrogenated with $\mathrm{PtO}_{2}$ in acetic acid $(99 \%)$. Hydrogen was bubbled through for $2 \mathrm{~h}$ and the solution was stirred for an additional $24 \mathrm{~h}$ at 


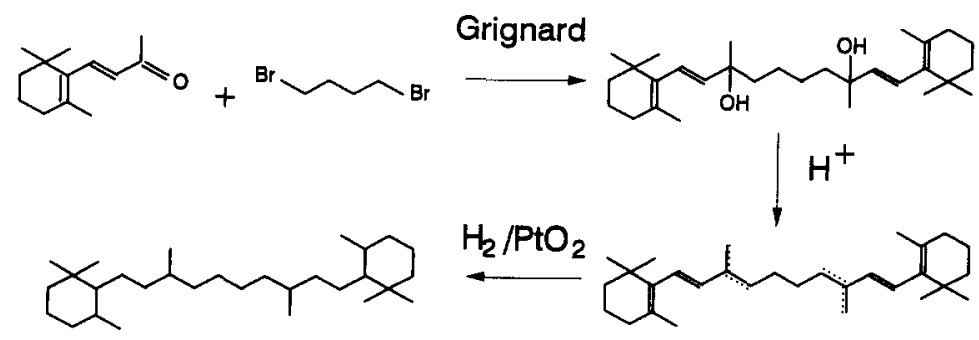

FIG. 1. Synthetic route for synthesis of 1,10-bis $\left(2^{\prime}, 2^{\prime}, 6^{\prime}\right.$-trimethylcyclohexyl)-3,8-dimethyldodecane (I).

room temperature. The desired product, 1, 10-bis $\left(2^{\prime}, 2^{\prime}, 6^{\prime}\right.$-trimethylcyclohexyl)-3,8-dimethyldodecane, was isolated from the reaction mixture, using high pressure liquid chromatography (HPLC). The sample (ca. $35 \mathrm{mg}$ ) was separated using a Porosil $\mathrm{C}_{18}$ semipreparative column (Waters) and ethylacetate/methanol $(20: 80 \mathrm{v} / \mathrm{v})$ as eluent. Appropriate subfractions were combined and separated further using a Novapak $\mathrm{C}_{18}$ analytical column (Waters) with ethylacetate/methanol $(20: 80 \mathrm{v} / \mathrm{v})$ as eluent. Finally, a fraction of $3.9 \mathrm{mg}$ of 1,10 bis $\left(2^{\prime}, 2^{\prime}, 6^{\prime}\right.$-trimethylcyclohexyl)-3,8-dimethyldodecane was obtained with a GC-purity higher than $95 \%$. The compound was characterized by ' $\mathrm{H}-\mathrm{NMR}\left(400 \mathrm{MHz}\right.$ in $\left.\mathrm{CDCl}_{3}\right) ; \delta(\mathrm{ppm}): 0.84$ (doublet, $6 \mathrm{H}, J=7.2 \mathrm{~Hz}$, methylgroups on $\mathrm{C} 3-$ and $\mathrm{C}-8$ ), 0.85 (doublet, $6 \mathrm{H}$, $J=6.4 \mathrm{~Hz}$, methylgroups on $\mathrm{C} 2{ }^{\prime}$ and $\mathrm{C}-2$ "), 0.86 ( singlet, $6 \mathrm{H}$, axial methylgroups $\mathrm{C}^{\prime}$ and $\mathrm{C}^{\prime \prime}$ ), 0.93 (singlet, $6 \mathrm{H}$, equatorial methylgroups $\mathrm{C}^{\prime}$ and $\mathrm{C}^{\prime \prime}$ ), 1.00-1.50 (multiplets, $32 \mathrm{H}$ ), and 1.84-1.94 (multiplet, 2H, $\mathrm{H}$ 's of $\mathrm{Cl}^{\prime}$ and $\mathrm{Cl}^{\prime \prime}$ ).

\section{Gas Chromatography}

GC was performed using a Hewlett Packard 5890 equipped with an on-column injector. A fused silica capillary column $(25 \mathrm{~m} \times 0.32$ $\mathrm{mm}$ ) coated with CP Sil-5 (film thickness $0.12 \mu \mathrm{m}$ ) was used with helium as carrier gas. For the coinjection experiments, a capillary column $(50 \mathrm{~m} \times 0.33 \mathrm{~mm}$ ) coated with Ultra-1 (thickness $0.2 \mu \mathrm{m}$ ) was also used. Both a flame ionization detector (FID) and a sulphurselective flame photometric detector (FPD) were used, requiring a stream-splitter at the end of the column (split ratio FID:FPD $=1: 4$ ). The samples were dissolved in ethyl acetate and injected at $70^{\circ} \mathrm{C}$. Subsequently, the oven was programmed to $130^{\circ} \mathrm{C}$ at $20^{\circ} \mathrm{C} / \mathrm{min}$ and then at $4^{\circ} \mathrm{C} / \mathrm{min}$ to $320^{\circ} \mathrm{C}$ at which it was held for $15 \mathrm{~min}$.

\section{Gas Chromatography-Mass Spectrometry}

GC-MS was performed using a Hewlett-Packard 5890 gas chromatograph interfaced to a VG Autospec Ultima mass spectrometer operated at $70 \mathrm{eV}$ with a mass range of $m / z 40-800$ and a cycle time of $1.7 \mathrm{~s}$ (resolution 1000). The gas chromatograph was equipped with a fused silica capillary column $(25 \mathrm{~m} \times 0.32 \mathrm{~mm})$ coated with CP Sil-5 (film thickness $=0.2 \mu \mathrm{m}$ ). The carrier gas was helium. The samples were on column injected at $60^{\circ} \mathrm{C}$ and subsequently the oven was programmed to $130^{\circ} \mathrm{C}$ at $20^{\circ} \mathrm{C} / \mathrm{min}$ and then at $4^{\circ} \mathrm{C} / \mathrm{min}$ to $300^{\circ} \mathrm{C}$ at which it was held for $10 \mathrm{~min}$.

\section{Isotope-Ratio-Monitoring Gas Chromatography-Mass} Spectrometry

The DELTA-C irm-GC-MS-system is in principal similar to the DELTA-S system as has been described previously (Hayes et al. 1990). The gas chromatograph was equipped with a fused silica capillary column $(25 \mathrm{~m} \times 0.32 \mathrm{~mm}$ ) coated with CP Sil-5 (film thickness $=0.2 \mu \mathrm{m}$ ) with helium as carrier gas. The samples (dissolved in hexane or ethylacetate) were on-column injected at $70^{\circ} \mathrm{C}$ and subsequently, the oven was programmed to $130^{\circ} \mathrm{C}$ at $20^{\circ} \mathrm{C} / \mathrm{min}$, and then at $4^{\circ} \mathrm{C} / \mathrm{min}$ to $320^{\circ} \mathrm{C} / \mathrm{min}$ at which it was held for $20 \mathrm{~min}$. The isotopic values were calculated by integrating the mass 44,45 , and 46 ion currents of the peaks produced by combustion of the chromatographically separated compounds and that of $\mathrm{CO}_{2}$-spikes produced by admitting $\mathrm{CO}_{2}$ with a known ${ }^{13} \mathrm{C}$-content at regular intervals into the mass spectrometer. Values reported were determined by at least two analyses and the results were averaged to obtain a mean value and to calculate the standard deviation. The stable carbon isotope compositions are reported in the delta notation against the PDB ${ }^{13} \mathrm{C}$ standard.

\section{RESULTS AND DISCUSSION}

\section{Identification of 1,10-bis $\left(2^{\prime}, 2^{\prime}, 6^{\prime}\right.$-trimethylcyclohexyl)- 3,8-dimethyldodecane [I]}

GC-analysis of several alkylsulphide fractions of immature sulphur-rich sediments (Cretaceous Jurf ed Darawish Oil Shale, Miocene Vena del Gesso Basin, and Miocene Monterey Formation) revealed a novel compound present in relatively high amounts. In the sample from the Monterey Formation this compound is dominating this fraction (Fig. 2b). Based on the response of the sulphur-selective flame-photometric-detector, it contains two sulphur atoms (Fig. 2c). Its mass spectrum (Fig. 2a) is dominated by the molecular ion at $m / z 478$ and possesses some smaller fragments at $m / z 168$, 211,308 , and 409. An unidentified compound with an identical mass spectrum has been reported in Monterey samples from Point Arena and in a sample from the Tertiary Ozouri Formation (Gabon; de Lemos Scofield, 1990). The mass spectrum shows many similarities with that of a thiane possessing a $\beta, \beta$-carotane carbon skeleton (V), previously tentatively identified by Trifilieff (1987). This sulphur compound has mass fragments of $\mathrm{m} / z 69,211$, and 518 and a molecular ion at $m / z 588$. The difference of 110 daltons of the molecular weight compared to that of the novel sulphur compound may be explained by an additional sulphur-atom (as determined by the FPD-response) and ten carbon atoms less. This led us to propose the structure as shown in Fig. 2 for the novel sulphur compound (VI). The broadness of the chromatographic peak suggests that the sedimentary compound is composed of several steroeisomers consistent with its proposed structure. To confirm this hypothetical structure, the alkylsulphide fraction of Shell Beach was desulphurized. The usual Raney nickel and nickel boride desulphurization techniques ( Schouten et al., 1993) were, however, not effective on this sulphur compound, probably due to the severe steric protection of the methyl-groups and the cyclohexylrings. Desulphurization under "forcing conditions"' (Raney nickel, cyclohexane, sealed tube, $200^{\circ} \mathrm{C}, 3 \mathrm{~h}$; Payzant et al., 1986 ) yielded a mixture of unsaturated compounds. This mixture was first hydrogenated using standard techniques $\left(\mathrm{H}_{2}\right.$, $\mathrm{PtO}_{2}$, ethyl acetate, room temperature; Sinninghe Damsté et al., 1989), but these failed to hydrogenate the unsaturated compounds, probably due to steric hinderance of the cyclohexyl-rings. By using 99\% acetic acid as solvent and pro- 


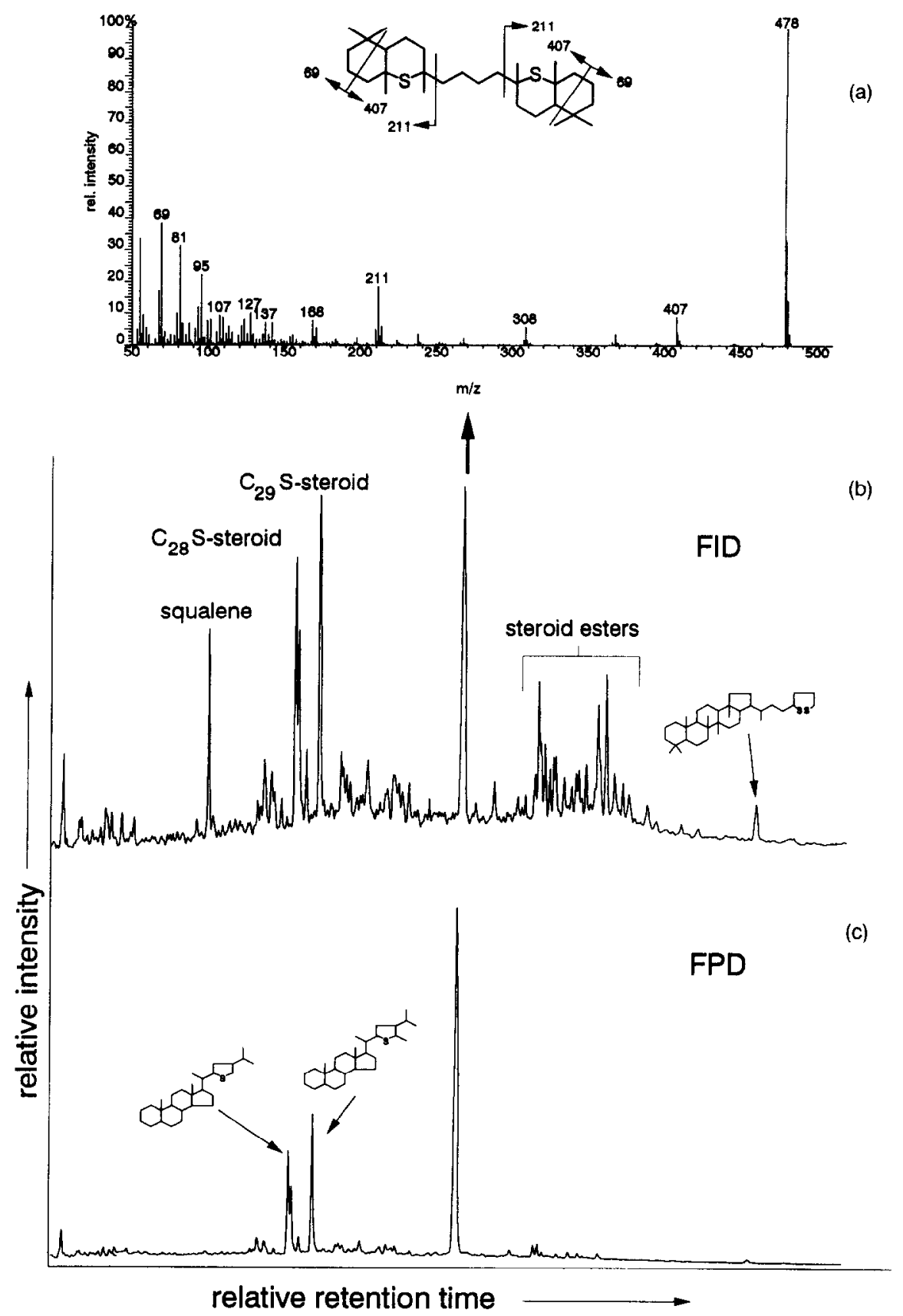

FiG. 2. Gas chromatogram of alkylsulphide-fraction of Shell Beach (Monterey Formation). (a) Mass spectrum of dominant sulphur compound, (b) FID-trace, and (c) FPD-trace.

longed stirring, hydrogenation of the unsaturated compounds was finally achieved. An abundant compound eluting just before the $\mathrm{C}_{28}$ n-alkane (Fig. 3 ) in the desulphurized and hydrogenated alkylsulphide fraction represents the desulphurized counterpart of the novel sulphur compound. This was confirmed by comparison of the carbon isotopic composition of the sulphur compound $(-32.6 \pm 0.2 \% o)$ with that of its desulphurized counterpart $(-32.8 \%$ ), which are unique values in the fractions analyzed. The mass spectrum of the desulphurized counterpart indicates a $\mathrm{C}_{30}$ alkane with two rings. To prove its structure 1,10 -bis $\left(2^{\prime}, 2^{\prime}, 6^{\prime}\right.$-trimethylcyclohexyl)-3,8-dimethyldodecane (I) was synthesized (Fig. 1). The mass spectrum of the synthetic compound is identical to that of the sedimentary compound (Fig. 3 ) and coinjection experiments on two different GC-columns (CP-Sil 5 and Ultra-1) revealed that they have identical retention times, thus proving the structure of the desulphurized sedimentary compound to be 1,10 -bis $\left(2^{\prime}, 2^{\prime}, 6^{\prime}\right.$-trimethylcyclohexyl $)$-3,8-dimethyldodecane [I].

Origin of 1,10-bis $\left(2^{\prime}, 2^{\prime}, 6^{\prime}\right.$-trimethylcyclohexyl $)-3,8$ dimethyldodecane [I]

To the best of our knowledge, this unambiguously identified $\mathrm{C}_{30}$ bicyclic triterpenoid carbon skeleton has not becn 

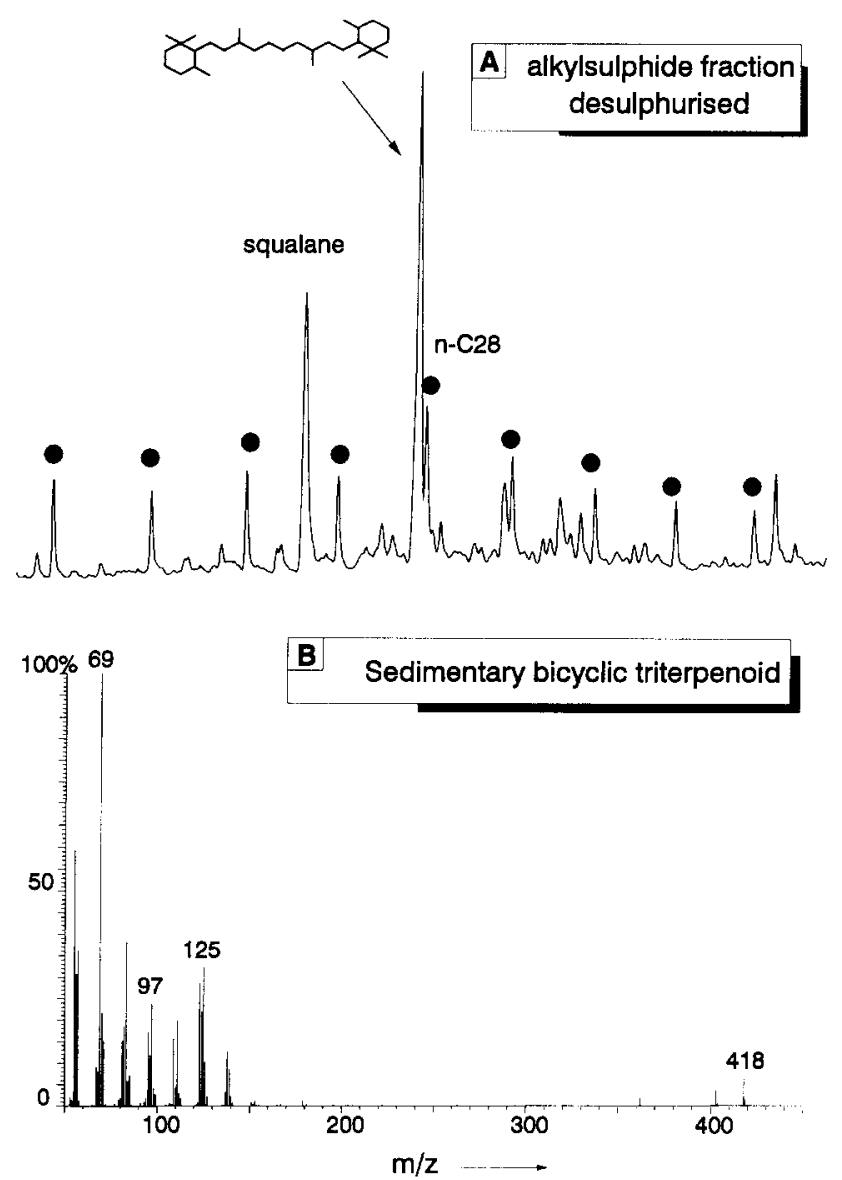

FIG. 3. (A) Gas chromatogram of desulphurized alkylsulphidefraction and (B) mass spectrum of the dominant compound 1,10bis $\left(2^{\prime}, 2^{\prime}, 6^{\prime}\right.$-trimethylcyclohexyl)-3,8-dimethyldodecane (I). $\bullet=n$ alkanes.

reported before in Nature. This carbon skeleton shows many structural similarities with that of $\beta, \beta$ carotene (III) . $\beta, \beta$-Carotene is a carotenoid, which occurs widespread in plants and organisms and is a metabolite derived from cyclization of lycopene (IV; Nes and McKean, 1977; Ratledge and Wilkinson 1989; Fig. 4). It may thus be suggested that the $C_{30}$ bicyclic triterpenoid is derived from a $\mathrm{C}_{30}$ carotenoid (VII). Indeed, in some bacteria acyclic $\mathrm{C}_{30}$ carotenoids do occur (Taylor, 1984), but cyclization of these compounds has never been reported. This process is deemed unlikely, since all double bonds are conjugated, thereby inhibiting enzymes to cyclisize $\mathrm{C}_{30}$ carotenoids in contrast to lycopene (Taylor, 1984).

Alternatively, the bicyclic triterpenoid carbon skeleton may have been derived from a novel cyclization reaction of squalene. Squalene or its epoxide can be cyclisized through catalysis of different enzymes to amongst others steroids, hopanoids and tetrahymanol. In rare cases, cyclization of the terminal isoprene-units of squalene has been reported leading to the formation of a tricyclic compound ambrein (VIII; Nes and McKean, 1977) and a tetracyclic compound, onocerin (IX; Nes and McKean, 1977). Theoretically, however, the possibility of an cnzymatic cyclization of squalene leading to a bicyclic compound, similar to lycopene leading to $\beta, \beta$-carotene, is not excluded since the double bonds are in the appro- priate positions and are not conjugated (Nes and McKean, 1977). Additional evidence for this hypothesis is provided by the mode of occurrence of the carbon skeleton in the sediments. Cyclization of squalene could lead to a $\mathrm{C}_{30}$ bicyclic triterpenoid possessing four double bonds. Since there are less than four $\mathrm{sp}^{3}$-hybridized carbon atoms between the double bonds, it can be expected that intramolecular sulphur-incorporation is favoured, leaving no double bonds for the formation of intermolecular sulphur-linkages (Schouten et al., 1994; de Graaf et al., 1992). Indeed, no macromolecularly sulphur-bound compounds possessing the $\mathrm{C}_{30}$ bicyclic triterpenvid carbon skeletun were detected in the sedinents investigated (Schouten et al., 1995). Furthermore, the tentative structure of the sulphur compound proposed on basis of its mass spectrum would be in full agreement with intramolecular incorporation of sulphur at the double bond positions proposed. In contrast, sulphur-bound $\beta, \beta$-carotane carbon skeletons have only been released from macromolecular fractions (Trifilieff, 1987; Schouten et al., 1994). This is attributed to the multiple double bonds in the precursor biochemical $\beta, \beta$ carotene making it statistically likely that at least one of the many formed sulphur-linkages is intermolecular (Fig. 4).

The question remains which organism biosynthesize (d) the $\mathrm{C}_{30}$ bicyclic triterpenoid carbon skeleton from squalene and for what purpose. From our limited sample set, we can infer that this compound was biosynthesized, at least in coastal marine and hypersaline lagoonal depositional environments in the Miocene and in a shallow marine basin during the Cretaceous. This suggests that this compound is not unique to certain depositional settings and/or time spans. Compound specific isotope analysis of both the sulphur compound and the desulphurized counterpart revealed a $\delta{ }^{13} \mathrm{C}$-value of -32.7 $\pm 0.2 \%$. This value is several per mill lighter than that of the algal-derived steroids $\left(\delta^{13} \mathrm{C}=-25\right.$ to $-27 \%$; Schouten et al., 1995) and of the cyanobacterial-derived $C_{35}$ hopane $(\delta$ ${ }^{13} \mathrm{C}=-27.7 \%$; Schouten et al., 1995). Thus, the ${ }^{13} \mathrm{C}$-content falls outside the range of other squalene-derived biomarkers from organisms living in the photic zone. The relatively depleted $\delta{ }^{13} \mathrm{C}$-value for [VI] may suggest that its bicyclic precursor (Fig. 4) is derived from organisms living deeper in the water column, possibly chemoautotrophic bacteria.

The reason why this compound has not been reported in contemporary organisms may be twofold: either it still has to be detected in cultures or field samples or the organism biosynthesizing this squalene derivative has disappeared during evolution. Since part of the structure of ambrein, derived from intestinal bacleria (Nes and McKean, 1977), is similar to the structure of the bicyclic triterpenoid a bacterial source may tentatively be suggested. The biological purpose of this compound is also not clear. Since the precursor biochemical did not possess conjugated double bonds like carotenoids a biological purpose as pigment can be excluded. Another possibility would be that this compound acts as a membrane rigidifier similar to steroids (Ratledge and Wilkinson, 1989) and hopanoids (Ourisson et al., 1987; Ratledge and Wilkinson, 1989 ) in eukaryotes and prokaryotes, respectively. However, the molecular dimensions of this molecule do not favour this hypothesis. Until this compound is detected in contemporary organisms suggestions concerning its origin and biological purpose will remain speculative. 
LYCOPENE

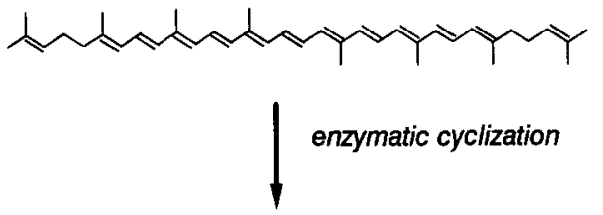

e.g. B,B-CAROTENE<smiles>C=C1CCCC(C)(C)/C1=C\C(C)=C\C=C\C(C)=C\C=C\C=C(C)\C=C\C=C(C)\C=C\C1=C(C)CCCC1(C)C</smiles>

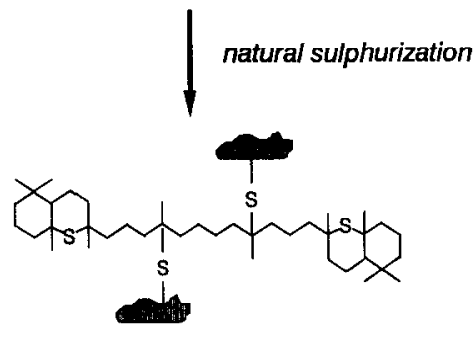

SQUALENE
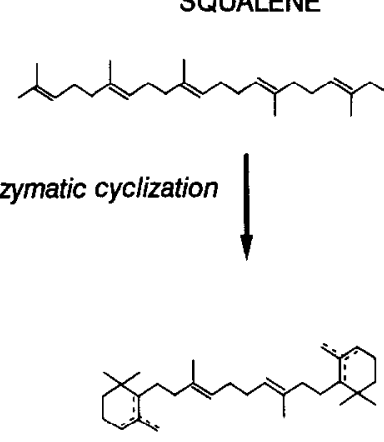

natural sulphurization

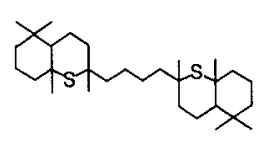

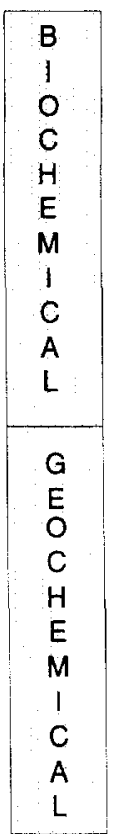

FiG. 4. Graphic representation of the proposed biochemical reactions and geochenical reactions with lycopene and squalene.

\begin{abstract}
Acknowledgments-W. I. C. Rijpstra, W. Pool, and M. Dekker are thanked for analytical assistance. Ir. A. Sinnema is thanked for the NMR-analysis. We thank the Chevron Petroleum Technology Company (La Habra) for financial support and permission to publish data on the Monterey sample. This work was partly supported by a Pionier grant to JSSD from the Netherlands Organization for Scientific Research (NWO). We thank Shell International Petroleum Maatschappij BV for financial support for the irm-GC-MS facility. Dr. R. E. Summons and three anonymous referees are thanked for their constructive reviews. This paper is NIOZ Division of Marine Biogeochemistry contribution no. 355 .
\end{abstract}

\section{Editorial handling: J. D. Macdougall}

\section{REFERENCES}

Adam P., Trendel J. M., and Albrecht P. (1991) Novel thiophene derived from higher plant triterpenes in sediments. Tetrahedron Lett. 32, 4179-4182.

De Graaf W., Sinninghe Damsté J. S., and de Leeuw J. W. (1992) Laboratory simulation of natural sulphurization I. Formation of monomeric and oligomeric isoprenoid polysulphides by low-temperature reactions of inorganic polysulphides with phytol and phytadienes. Geochim. Cosmochim. Acta 56, 4321-4328.

de Lemos Scofield A. (1990) Nouveaux marqueurs biologiques de sediments et petroles riches en soufre: identification et mode de formation. Ph.D. dissertation, Univ. Strasbourg.

Hayes J. M., Freeman K. H., Popp B. N., and Hoham C. H. ( 1990) Compound-specific isotope analysis: A novel tool for reconstruction of ancient biogeochemical processes. In Advances in Organic Geochemistry 1989 (ed. B. Durand and F. Behar); Org. Geochem. 16, pp. $1115-1128$.

Johns R. B. (1986) Biological Markers in the Sedimentary Record; Meth. Geochem. Geophys. 24. Elsevier.

Kohnen M. E. L., Sinninghe Damsté J. S., Rijpstra W. I. C., and de Leeuw J. W. (1990) Alkylthiophenes as sensitive indicators of paleonvironmental changes: A study of a Cretaceous oil shale from Jordan. In Geochemistry of Sulfur in Fossil Fuels (ed. W. L. Orr and C. M. White); ACS Symp. Ser. 249, pp. 444-485.

Kohnen M. E. L., Sinninghe Damsté J. S., Kock-Dalen A. C., and de Leeuw J. W. (1991) Di- or polysulphide-bound biomarkers in sulphur-rich geomacromolecules as revealed by selective chemolysis. Geochim. Cosmochim. Acta 55, 1375-1394.
Kohnen M. E. L. et al. (1992) The combined application of organic sulphur and isotope geochemistry to assess multiple sources of palaeobiochemicals with identical carbon skeletons. In Advances in Organic Geochemistry 1991 (ed. C. B. Eckhardt et al.); Org. Geochem. 19, pp. 403-420.

Nes W. R. and McKean M. L. (1977) Biochemistry of Steroids and Other Isopentenoids. University Park Press.

Nichols P., Volkman J. M., Palmisano A., Smith G., and White D. (1988) Occurrence of an isoprenoid $C_{25}$ diunsaturated alkene and high neutral lipid content in Antarctic sea-ice diatom communities. J. Phyc. 24, 9096.

Ourisson G., Poralla K., and Rohmer M. (1987) Prokaryotic hopanoids and other polyterpenoid sterol surrogates. Ann. Rev. Microbiol. 41, 301-333.

Payzant J. D., Montgomerey D. S., and Strausz O. P. (1986) Sulfides in petroleum. Org. Geochem. 9, 357-369.

Peters K. E. and Moldowan J. M. (1993) The Biomarker Guide. Prentice Hall.

Philp R. P. (1985) Fossil Fuel Biomarkers, Methods in Geochemistry and Geophysics, Vol. 23. Elsevier.

Ratledge C. and Wilkinson S. G. (1989) Microbial Lipids, Vols. 1 and 2. Academic Press.

Schmid J. C. (1986) Marqueurs biologiques soufrés dans les pétroles. Ph.D. dissertation, Univ. Strasbourg.

Schouten S., Pavlović D., Sinninghe Damsté J. S., and de Leeuw J. W. (1993) Nickel boride: An improved desulphurizing agent for sulphur-rich geomacromolecules in polar and asphaltene fractions. Org. Geochem. 20, 901-909.

Schouten S., de Graaf W., Sinninghe Damsté J. S., Van Driel G. B., and de Leeuw J. W. (1994) Laboratory simulation of natural sulphurization: II. Reaction of multi-functionalized lipids with inorganic polysulphides. In Advances in Organic Geochemistry 1993 (eds. K. Oygard et al.); Org. Geochem. 22, 825-834.

Schouten S., Schoell M., Rijpstra W. I. C., Sinninghe Damsté J. S., and J. W. de Leeuw (1995) Molecular biugeuchemistry of Monterey sediments III: Distribution and stable carbon isotopic compositions of free and sulphur-bound carbon skeletons in sediment extracts from Shell Beach (Pismo Basin), in preparation.

Sinninghe Damsté J. S.. Rijpstra W. I. C.. Kock-Van Dalen A. C.. de Leeuw J. W., and Schenck P. A. (1989) Quenching of labile functionalised lipids by inorganic sulphur species: Evidence for the formation of sedimentary organic sulphur compounds at the early 
stages of diagenesis. Geochim. Cosmochim. Acta 53, 14431455.

Taylor R. F. ( 1984) Bacterial triterpenoids. Microbiol. Rev. 48, 181-198. Trifilieff S. (1987) Etude de la structure des fractions polaires de pétroles (résins et asphaltenes) par dégradations chimiques sélectives. Ph.D. dissertation, Univ. Strasbourg.
Volkman J. K., Barret S. M., and Dunstan G. A. (1994) $\mathrm{C}_{33}$ and $\mathrm{C}_{30}$ highly branched isoprenoid alkenes in laboratory cultures of two marine diatoms. Org. Geochem. 21, 407-413.

Yon D. A., Maxwell J. R., and Ryback G. (1982) 2,6,10-Trimethyl7-(3-methylbutyl)dodecane, a novel sedimentary biological marker. Tetrahedron Lett. 23, 2143-2146.

\section{APPENDIX}<smiles>CC(CCCCC(C)CC1C(C)CCCC1(C)C)CCC1(C)OC2(C)CCC1(C)CCC2C</smiles><smiles>CC1=C(/C=C/C=C(C)/C=C/C=C(C)/C=C/C=C/C=C(C)/C=C/C=C(C)/C=C/C2=C(C)CCCC2(C)C)C(C)(C)CCC1</smiles>

III<smiles>CC(CCCCC(C)CCC1C(C)CCCC1(C)C)CCCC(C)CCCC1(C)CCC2C(C)(C)CCCC2(C)S1</smiles>

$\mathbf{V}$

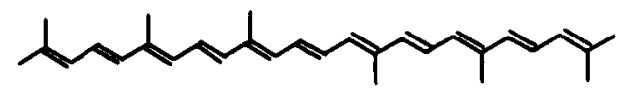

VII

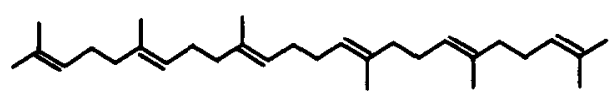

II

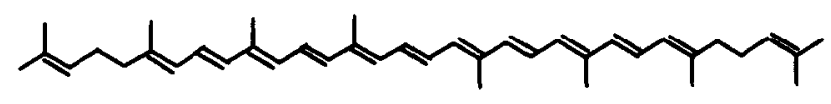

IV

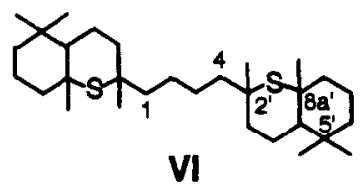

V

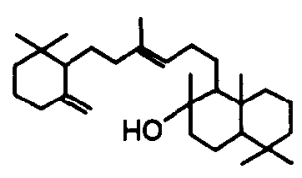

VIII

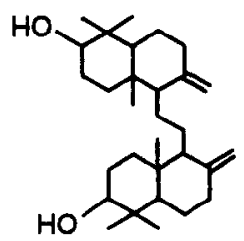

IX 